\title{
Internalisasi Nilai-Nilai Kepemimpinan Islam dalam Organisasi Santri Pesantren \\ (Penelitian di Pesantren Ibnu Siena Mulia Cikoneng Kabupaten Ciamis)
}

\author{
Muhammad Arif Ridwan \\ Institut Agama Islam Darussalam (IAID), Ciamis-Jawa Barat \\ Email: moh.arifridwan@gmail.com \\ Hasanudin \\ Institut Agama Islam Darussalam (IAID), Ciamis-Jawa Barat \\ Imas Masturoh \\ Institut Agama Islam Darussalam (IAID), Ciamis-Jawa Barat
}

\begin{abstract}
This study aims: (1) To find out how to plan the internalization of leadership values through the Islamic Boarding School Ibnu Siena Mulia (OSPIS) santri organization. (2) To find out how the implementation of the internalization of leadership values through the Islamic boarding school santri Ibnu Siena Mulia organization. (3) To find out how the results of the internalization of leadership values through the Pesantren Ibnu Siena Mulia santri organization. This research is a qualitative field research. Data collection was carried out by using interview, observation and documentation techniques. The data analysis technique used is descriptive analysis. The results of this study indicate that: 1) Planning the internalization of leadership values in the OSPIS Ibnu Siena Mulia Islamic Boarding School is carried out in 4 steps. The first step is the formation of the committee, the second step is the reporting of the old OSPIS committee, the third step is the election of the new OSPIS chairman, and the fourth step is the formation of the new OSPIS structure. 2) The internalization of leadership values in the Ibnu Siena Mulia Islamic Boarding School OSPIS is carried out through the division of divisions with their respective main duties and functions. The internalization of leadership values is carried out in five forms, namely lectures, education, uswah hasanah, training and the environment. 3) Internalization of leadership values in the Ibnu Siena Mulia Islamic Boarding School OSPIS can be felt by the board and boarding school with the formation of an attitude of trust, responsibility, social spirit and good role models.
\end{abstract}

Keywords: Organization, Santri, Pesantren, Internalization, Leadership 


\section{PENDAHULUAN}

Internalisasi secara terminologi berasal dari kata "intern". Menurut Poerwadarminta (2003: 450) dalam bukunya Kamus Umum Bahasa Indonesia "intern" bermakna dalam lingkungan (kalangan) sendiri, urusan-urusan di lingkungan sendiri. Selanjutnya, berlandaskan pada arti terminologinya, Nasukah, (2020: 62) mendefinisikan Internalisasi sebagai suatu penghayatan nilai-nilai dan atau norma-norma sehingga menjadi kesadaran yang diwujudkan dalam sikap dan perilaku.

Istilah Internalisasi kerap dijumpai di ranah kegiatan pendidikan dan pengajaran. Dalam kegiatan pembelajaran, internalisasi dapat dilakukan dengan menyisipkan nilai-nilai tersebut kepada siswa saat pembelajaran mata pelajaran tertentu. Adapun dalam ranah dunia pendidikan, internalisasi dapat dilakukan baik dalam kegiatan administratif oleh pengelola dan dalam kegiatan pembelajaran (Nasukah, 2020: 64).

Internalisasi sebagai sebuah proses panjang. Bahkan ada yang mendefinisikan internalisasi sebagai suatu proses pengahayatan sebuah ajaran atau nilai sepanjang hidupnya. Proses yang tidak singkat itu, dirumuskan oleh Widyaningsih (2014: 182) dalam tiga tahap yaitu: (1) Tahap transformasi nilai, di mana dalam tahap ini pendidik sekedar menginformasikan nilai-nilai yang baik dan yang kurang baik kepada siswa yang semata-mata komunikasi searah. (2) Transaksi nilai yakni suatu tahap pendidikan nilai dengan jalan melakukan komunikasi dua arah, atau interaksi antara peserta didik dengan pendidik yang bersifat interaksi timbal balik secara aktif. Dalam tahap ini pendidik tidak hanya memberikan informasi tentang nilai-nilai tetapi juga terlibat dalam proses menerima dan melaksanakan nilai-nilai itu. (3) Tahap internalisasi, pada tahap ini jauh lebih dalam yang juga melibatkan tidak hanya aspek fisik, tetapi telah menyangkut sikap mental kepribadian baik bagi pendidik maupun peserta didiknya.

Nilai merupakan sesuatu yang melekat pada diri manusia yang patut untuk dijalankan dan dipertahankan, sebagai makhluk ciptaan Tuhan yang mempunyai karakter khas dari pada makhluk yang lain. Manusia mempunyai akal, perasaan, hati nurani, kasih sayang, moral, budi pekerti, dan etika adalah merupakan karakter khas manusia dibandingkan dengan makhluk yang lainnya, dan karakter inilah yang melekat pada diri manusia sebagai bentuk dari nilai itu sendiri.

nilai sejatinya memiliki fungsi utama yaitu sebagai prinsip-prinsip umum dalam bertindak atau bertingkah laku manusia. Nilai menjadi pagar batasan-batasan perilaku baik dan buruk, mana yang harus dikerjakan, dan mana yang harus dihindari.

Nurseno (2011: 43) memperinci fungsi nilai baik dalam masyarakat, maupun individu. Berikut beberapa fungsi nilai yang ia utarakan: (1) Nilai menyumbangkan seperangkat alat yang siap dipakai untuk menetapkan harga sosial dari pribadi dan kelompok. Nilai memungkinkan sistem stratifikasi secara menyeluruh yang ada pada setiap masyarakat. (2) Cara- 


\section{BESTARI}

Vol. 17, No. 2, 2020

p-ISSN 1907-1337; e-ISSN 2807-6532

cara berpikir dan bertingkah laku secara ideal dalam sejumlah masyarakat diarahkan atau dibentuk oleh nilai. Hal ini terjadi karena anggota masyarakat selalu dapat melihat cara bertindak dan bertingkah laku yang terbaik. dan ini sangat memengaruhi dirinya sendiri. (3) Nilai merupakan penentu terakhir bagi manusia dalam memenuhi perananperanan sosialnya. Mereka menciptakan minat dan memberi semangat pada manusia untuk mewujudkan sesuatu yang diminta dan diharapkan oleh peranan-peranannya menuju tercapainya sasaran-sasaran dalam masyarakat. (4) Nilai dapat berfungsi sebagai alat pengawas dengan daya tekan dan daya mengikat . tertentu. Mereka mendorong, menuntun, dan kadang-kadang menekan manusia untuk berbuat baik. Nilai menimbulkan perasaan bersalah yang cukup menyiksa bagi orangorang yang melanggarnya. (5) Nilai dapat berfungsi sebagai alat solidaritas di kalangan anggota kelompok dan masyarakat

Proses Internalisasi Nilai yang menjadi objek internalisasi oleh Pesantren Ibnu Siena Mulia dalam Organisasi Internalnya adalah nilai kepemimpinan Islam. Nilai kepemimpinan islam merupakan nilai kepemimpinan secara umum dengan beberapa eksklusifitas.

Definisi Kepemimpinan secara umum menurut Ma'sum (2019: 85) berasal dari kata "pimpin" yang berarti "(dalam keadaan) dibimbing; dituntun". Adapun adanya imbuhan ke-pe- di awal dan-an di akhir berarti "perihal pemimpin; cara pemimpin". Adapun kata "pimpin" memuat dua hal pokok, yaitu pemimpin sebagai subjek, dan yang dipimpin sebagai objek. Hal ini menunjukkan bahwa Pemimpin sebagai subjek mempunyai tanggung jawab, baik secara fisik maupun spiritual terhadap keberhasilan aktivitas kerja dari yang dipimpin (Saebani, 2014: 27).

Locke (dalam Hajar, 2019: 63) mendefinisikan kepemimpinan sebagai suatu proses membujuk (inducing) orang-orang lain menuju sasaran bersama. Locke menambahkan bahwasannya ada tiga elemen sebagai cakupan dari definisi kepemimpinan yang ia utarakan: (1) Kepemimpinan merupakan suatu konsep relasi (relational concept). Kepemimpinan hanya ada dalam proses relasi dengan orang lain (para pengikut). Apabila tidak ada pengikut, maka tidak ada pemimpin. (2) Kepemimpinan merupakan suatu proses. Agar bisa memimpin, pemimpin harus melakukan sesuatu. (3) Kepemimpinan harus membujuk orang-orang lain untuk mengambil tindakan. Pemimpin membujuk pengikutnya melalui berbagai cara, seperti menggunakan otoritas yang terlegitimasi, menciptakan model (menjadi teladan),

penetapan sasaran, memberi imbalan dan hukum, restrukturisasi organisasi, dan mengkomunikasikan visi (Hajar, 2019: 63-64).

Seorang pemimpin haruslah menjalankan tugas dan fungsi kepemimpinannya. Jika kepemimpinan hanya dianggap sebagai jabatan, pengkat atau kedudukan, maka kepemimpinan dianggap nihil dan tidak bermanfaat apapun bagi orang-orang yang dipimpinnya. Al Hamdani 
(2005: 94) berpandangan bahwa pemimpin dengan tugas dan fungsi kepemimpinannya merupakan sebuah kesatuan yang terintegrasi dalam mencapai tujuan suatu organisasi. Dalam prosesnya, dibutuhkan sistematika khusus dan melibatkan orang lain yang bersifat mengikuti perintah, arahan dan dorongan juga larangan.

Pesantren Ibnu Siena Mulia sebagai lembaga pendidikan Islam formal, memahami betul akan pentingnya nilai-nilai kepemimpinan. dan hal itu diharapkan bisa tertanam dalam jiwa setiap santrinya.

Nilai kepemimpinan Islam merupakan nilai-nilai yang Rosulullah SAW contohkan dan ajarkan kepada para sahabatnya. Niali tersebut diajarkan melalui metode Uswah hasanah.

Jika diklasifikasikan, gaya kepemimpinan Beliau bisa dikategorikan sebagai gaya kepemimpinan karismatik. Menurut Nadler dan Tushman (dalam Indartono, 2005: 50) gaya kepemimpinan semacam ini memiliki tiga tipe yaitu: (1) Tipe Envisioning, yaitu tipe yang menggambarkan pemimpin yang mampu memberikan gambaran masa depan, atau memberikan diskripsi apa yang akan terjadi di masa yang akan datang. (2) Tipe Energizing, yaitu tipe yang kepemimpinan yang mampu mengarahkan dan mengumpulkan semua energi, memotivasi untuk bertindak, diantara anggota organsasi atau terhadap yang dipimpinnya. (3) Tipe Enabling, yaitu tipe kepemimpinan yang secara psikologi mampu membantu orang untuk bergerak atau menghadapi sebuah target yang menantang.

Kepemimpinan dalam Islam dikenal dengan kata Khilafah. Allah berfirman dalam surat Albaqoroh ayat 30 tentang salah satu tujuan penciptaan manusia: "Ingatlah ketika Tuhanmu berfirman kepada para Malaikat: "Sesungguhnya Aku hendak menjadikan seorang khalifah di muka bumi". Mereka berkata: "Mengapa Engkau hendak menjadikan (khalifah) di bumi itu orang yang akan membuat kerusakan padanya dan menumpahkan darah, padahal kami senantiasa bertasbih dengan memuji Engkau dan mensucikan Engkau?" Tuhan berfirman: "Sesungguhnya Aku mengetahui apa yang tidak kamu ketahui" (Q.S. Al-Baqarah, 2:30).

Beekun dan Badawi (dalam Nasukah, 2020: 56) menambahkan, bahwasannya dalam kepemimpinan prespektif Islam, ada fokus umum yang harus dilakukan selama masa kepemimpinan, yaitu melakukan kebaikan. Upaya mendorong dan menggerakkan sumber daya pencapaian tujuan, harus disandarkan pada tujuan utama sebagai hamba Allah. Sehingga, penetapan tujuan hingga pencapaian tujuan tersebut harus tetap berada pada tujuan utama yaitu untuk beribadah kepada Allah.

Itulah sebabnya, kepemimpinan dalam perspektif Islam tidak bisa dilepaskan dari fokusnya untuk melakukan amal sholeh.Tujuan akhirnya adalah keridhaan Allah SWT. Hal ini sesuai dengan firman Allah SWT Alquran surah An-Nisa (4): 59 berikut: Hai orang-orang yang beriman, taatilah Allah dan taatilah Rasul (Nya), dan ulil amri di antara kamu. Kemudian jika kamu berlainan pendapat tentang sesuatu, maka kembalikanlah ia kepada Allah (Al Quran) dan Rasul (sunnahnya), jika 


\section{BESTARI}

Vol. 17, No. 2, 2020

p-ISSN 1907-1337; e-ISSN 2807-6532

kamu benar-benar beriman kepada Allah dan hari kemudian. Yang demikian itu lebih utama (bagimu) dan lebih baik akibatnya. An-Nisa (4): 59

Dari sudut pandang lain, sebagaiaman dikemukakan oleh Kuntowijoyo, Gaya kepemipinan Rosulullah merupakan gaya kepemimpinan Profetik. Profetik sendiri diambil dari kata prophet yang berarti Nabi atau Rosul. Esesnsi kepemimpinan profetik dirumuskan dalam alqur'an surat Ali Imran ayat 110: Kamu adalah umat yang terbaik yang dilahirkan untuk manusia, menyuruh kepada yang ma'ruf, dan mencegah dari yang munkar, dan beriman kepada Allah. Sekiranya Ahli Kitab beriman, tentulah itu lebih baik bagi mereka, di antara mereka ada yang beriman, dan kebanyakan mereka adalah orang-orang yang fasik.

Tiga landasan kepemimpinan profetik adalah pertama, humanisasi atau emansipasi dilandasi dari kalimat "ta "muruna bi alma'ruf", kedua, liberasi diderivasi dari kalimat "tanhauna 'anil-munkar", dan ketiga, transendensi diturunkan dari kalimat "tu'minuna billah" Ketiga nilai profetik ini dimaksudkan sebagai prasyarat menjadi umat yang terbaik (khair ummah). Dalam kaitannya dengan kepemimpinan profetik, ketiga nilai ini dapat menjadi landasan pemimpin dalam bersikap dan bertindak untuk mengarahkan segenap sumber daya yang dimiliki upaya mencapai tujuan. (Nasukah, 2020: 60).

Kepemimpinan Islam ini dituangkan dalam pengelolaan Pesantren Ibnu Siena Mulia, juga sama halnya dalam pengelolaan Organisasi Intra pesantrennya. Organisasi ini dinamakan OSPIS atau Organisasi santri Pesantren Ibnu Siena.

Pada dasarnya, OSPIS merupakan Organisasi secara umumnya, yaitu sebuah wadah yang berisikan struktur tata pembagaian kerja dan struktur tata hubungan kerja untuk bersama-sama untuk mencapai tujuan tertentu (Fitriyani. 2019: 64).. Pengurus OSPIS diharpakan dapat meninkatkan kemampuan dalam kepemimpinan sebagaimana tujuan awal adanya OSPIS ini.

Organisasi sebagaimana dikemukanan oleh Nurhadi (2013: 57) adalah wadah untuk membentuk dan mempelajari kepemimpinan dan bagaimana menjadi seorang pemimpin. Bimbaum (dalam Nurhadi, 2013: 57) berpendapat "Organisasi merupakan sarana belajar, bagaimana berpikir, bertindak, dan mengembangkan potensi diri, baik hard skill maupun soft skill"

Organisasi juga memiliki Struktur. Struktur dipandang penting dengan maksud pembagian kerja yang jelas sehingga bisa berfokus pada pencapaian pencapaian masing masing individu pada strukturnya sesuai tugas pokok dan fungsinya. Sofyan Syarif (dalam Fauzan, 2010: 116) mengemukakan kegunaan struktur organisasi, berikut ulasannya: (1) Mengarahkan arus perintah dan tanggungjawab, sehingga semua orang tahu kepada siapa ia bertanggungjawab dan kepada siapa ia memberikan intruksi. (2) Mempertegas tugas masing-masing dan menghindari 
tumpang tindih tugas. (3) Mempermudah penilaian dan koreksi. (4) Mengetahui siapa yang bertanggung jawab terhadap persoalan yang timbul. (5) Mempermudah pembagian tugas organisasi.

Menumbuhkan budaya berorganisasi.

\section{METODE}

Jenis penelitian yang penulis pakai adalah jenis penelitian kualitatif. Sugiyono (2017: 8) menjelaskan bahwasannya penelitian kualitatif seing disebut sebagai metode penelitian naturalistic karena penelitiannya dilakukan pada kondisi alamiyah (natural setting). Disebut natural, karena peneliti hanya menggambarkan menjelaskan dan mengungkapkan kejadian alamiyah tanpa adanya tindakan maupun percobaan apapun sehingga tidak ada generalisasi ataupun prediksi dari peneliti.

Peneliti memilih jenis penelitian ini dikarenakan objek penelitian bersifat alamiyah. Peneliti memandang kenyataan objek penelitian harus diteliti dengan apa adanya (natural). Sebagaimana paparan Loncoln dan Guba (dalam Sukmadinata, 2010: 60) bahwa naturalistik berarti kenyataan berdimensi jamak, sehingga perlu penjelasan deskriptif dalam rangka mengungkapkan hal-hal yang ada dibalik dimensi-dimensi tersebut, dan tentunya hal itu diluar ruang lingkup penelitian kuantitatif yang bersifat angka-angka. Pemilihan jenis penelitian ini diperkuat lagi oleh keterikatan peneliti dengan objek penelitan yang bersifat interaktif.

Metode yang digunakan dalam penelitian ini berlandaskan pada filsafat postpositivisme, yaitu metode deskriptif dimana peneliti adalah sebagai instrument kunci, teknik pengumpulan data dilakukan dengan cara triangulasi (gabungan), analilis data bersifat induktif/kualitatif, dan hasil penelitiannya lebih menekankan makna dari pada generalisasi (Sugiyono, 2017:9). Teori tidak menjadi acuan untuk mendapatkan datadata, namun fakta-fakta yang ditemukan saat penelitian di lapangan, dianalisis dan kemudian dikonstruksikan menjadi teori.

Metode penelitian kualitatif deskriptif sering disebut juga dengan metode kualiatatif interaktif. Dikatakan demikian karena metode kualitatif interaktif sejalan dengan pengertian metode kualitatif deskriptif yang menggunakan teknik pengumpulan data langsung dari orang dalam lingkungan alamiyah-nya.

Peneliti menggunakan metode penelitian kualitatif deskriptif karena pemilihannya dianggap perlu dan lebih efektif jika dibandingkan dengan jenis dan metode penelitian lain. Dalam kondisi naturalnya, baik peneliti maupun objek yang diteliti berada dalam satu lingkup yang interaktif, adanya timbal-balik dan penelitian ini melibatkan nilai nilai. Hal-hal yang telah disebutkan itu sejalan dengan konsep dan karakteristik penelitian metode kualitatif deskriptif. 
BESTARI

Vol. 17, No. 2, 2020

p-ISSN 1907-1337; e-ISSN 2807-6532

\section{HASIL DAN PEMBAHASAN}

Internalisasi Nilai-Nilai Kepemimpinan Islam Dalam Organisasi Santri pesantren Ibnu Siena Mulia Cikoneng Kabupaten Ciamis

Berdasarkan temuan peneliti di Lapangan, Perencanaan organisasi santri Pesantren Ibnu Siena Mulia (selanjutnya OSPIS) berasaskan pada MUSTRI (musyawarah santri) yang didalamnya secara garis besar terdapat 4 Tahapan. Tahapan Pertama yaitu Pembentukan Panitia Pelaporan, Kedua Pelaporan Pertangungjawaban OSPIS Lama ketiga Pemilihan Ketua OSPIS Baru dan ke empat Pembentukan Struktur OSPIS Baru.

MUSTRI berlangsung selama beberapa hari, tergantung waktu yang dijadwalkan oleh panitia MUSTRI sendiri. Dilansir dari laporan MUSTRI tahun ajaran 2019-2020 kemarin, pelaksanaannya berlangsung selama 4 hari, dimulai pada hari Jum'at yang bertepatan pada tanggal 8 November 2019 pukul 13.00 WIB dan berakhir pada hari senin, tanggal 11 november 2019 pukul 15.00 WIB.

Pembentukan Panitia Pelaporan

Panitia pelaporan terdiri dari santriwan dan santriwati Ibnu Siena Mulia kelas 11 dan 12 SMA. Pelaporan disampaikan oleh seluruh pengurus lama (santriwan/santriwati kelas 12) perdivisinya, yang nantinya akan dibacakan pada sidang Pleno pada langkah selanjutnya.

Adapun hal-hal yang perlu dipersiapkan panitia (terkhusus kelas 11) adalah mengagendakan jadwal pelaporan secara detail, dari mulai hari, dan jamnya. Kesekretariatan pun memiliki tugas untu membuat surat izin resmi kepada pihak Pesantren dan sekolah melalui kesantrian, mengingat agenda laporan pertanggungjawaban merupakan satu dari rentetan agenda pada MUSTRI yang nantinya seluruh santri akan diliburkan (sekolah) selama kurang lebihnya 3 hari berturut-turut.

Pelaporan Pertangungjawaban OSPIS Lama

Terdapat istilah khusus yang digunakan Pesantren untuk menamai agenda pelaporan pertanggungjawaban pengurus OSPIS lama, yaitu sidang pleno. Sidang pleno berisi penilaian terhadap laporan pertanggungjawaban pengurus OSPIS lama yang dilakukan dalam 3 termin atau lebih dan waktu pembicaraan ditentukan pimpinan sidang

Selanjutnya, sidang pleno diawali dengan pemilihan presidium, yaitu tiga orang terpilih dari 1 santri kelas 12 sebagai pimpinan sidang, 1 santri kelas 11 sebagai sekertaris dan 1 santri kelas 10 sebagai anggota. Pemilihan presidium ini dipimpin oleh presidium sementara, yaitu 3 santri kelas 12. Nantinya, presidium tetap bertugas memimpin jalannya sidang dan membacakan laporan pertanggung jawaban didepan seluruh peserta sidang.

Pemilihan Ketua OSPIS Baru

Pada langkah ini, terdapat 2 bentuk sidang. yang pertama adalah sidang komisi, yang berisikan pembacaan program kerja baru oleh bakal 
calon pengurus OSPIS baru, dan selanjutnya adalah sidang formatur, yang berisikan pemilihan 3 bakal calon ketua OSPIS baru, yang nantinya ketiga calon ini iakan dipilih secara umum oleh seluruh steakholder Pesantren, dari mulai pendiri Pesantren, Mudir, Asatidz, kesantrian dan seluruh santri Pesantren Ibnu Siena Mulia.

Sidang Komisi dipimpin oleh presidium, membacakan dan menetapkan AD/ART (anggaran dasar dan anggaran rumah tangga) OSPIS. Ia merupakan suatu dokumen yang menjadi landasan operasional dalam OSPIS. Anggaran Dasar (AD) berisikan pasal-pasal umum yang mengatur tentang OSPIS. Sidang timi formatur merupakan sidang dengant tujuan memilih 3 orang bakal calon ketua OSPIS. Tim formatur teridir dari 13 orang yang salah satunya merupakan ketua OSPIS lama.

Tim formatur, adalah mereka yang memilih 3 bakal calon ketua OSPIS baru yang nantinya akan dipilih lagi oleh seluruh santri, asatidz dan pendiri Pesantren seperti halnya pemilu. Nantinya, 3 calon ketua OSPIS akan memaparkan dan menjelaskan visi dan misinya didepan seluruh santri, asatidz dan pendiri Pesantren, kemudian panitia MUSTRI menyiapkan tempat dan bahan pemilihan berupa bilik pemilihan dan foto ketiga calon ketua OSPIS dalam selembar kertas yang nantinya secara bergiliran santri menyuarakan hak pilihnya dibalik bilik pemilihan.

Pembentukan Struktur OSPIS Baru

Setelah keluar hasil suara terbanyak pilihan seluruh steakholder Pesantren, dialah yang keluar menjadi Ketua OSPIS baru. Selanjutnya, tim formatur bertugas untuk merundingkan siapa dan di divisi apa, setiap santri kelas 11 akan ditempatkan. Tentunya pertimbangan kompetensi individu menjadi pertimbangan utama.

Setelah selesai, ada langkah terakhir yang harus dilakukan adalah membentuk tim perumus. Tim perumus adalah utusan-utusan per kelas guna merumuskan peraturan dan disiplin yang ditawarkan oleh divisi divisi dalm OSPIS. Tugas lainnya tim perumus adalah menyusun laporan hasil MUSTRI dari awal hingga akhir secara tertulis sebagai bahan laporan, pertimbangan dan evaluasi bagi kesantrian dan OSPIS di masa yang akan datang

\section{Pelaksanaan}

Pembahasan mengenai pelaksanaan pengurusan organisasi, lebih berfokus pada kinerja para pengurusnya dalam merealisasikan program kerja setiap divisi sebagaimana telah di direncanakan di awal. Dalam penjelasannya, peneliti akan menjelaskan struktur OSPIS santriwan, dan santriwati. Perlu diketahui bersama, bahwa dalam prakteknya, divisi OSPIS santriwan dan santriwati sepenuhnya dipisah. Hal ini merupakan kebijakan pihak Pesantren guna mengurangi interaksi antar non-muhrim di lingkungan Pesantren

Internalisasi merupakan bentuk proses, penghayatan, dan penanaman suatu nilai yang membutuhkan waktu panjang. Internalisasi dapat dijalankan dengan baik jika tahap prosesnya dijalankan dengan 


\section{BESTARI}

Vol. 17, No. 2, 2020

p-ISSN 1907-1337; e-ISSN 2807-6532

baik. salah satu tahapan itu adalah tranformasi nilai. Peneliti dalam hal ini menemukan setidaknya 5 bentuk transormasi tersebut.

1) Ceramah

Tranformasi nilai-nilai kepemimpinan acap kali dilakukan dengan metode ceramah. Walaupun dipandang sebagai metode tradisional, namun di beberapa Pesantren, sekolah dan lembaga pendidikan formal lainnya tidak meninggalkan metode ini.

Ceramah secara rutin dilakukan oleh pihak kesantrian, minimal sekali dalam sepekan. Yaitu saat agenda evaluasi OSPIS pada hari Senin malam. Tema ceramah disesuaikan dengan hal-hal yang sekiranya perlu. Materi ceramah biasanya dipersiapkan asatidz kesantrian sebelum agenda dimulai. Namun kadang kala materi ceramah yang diberikan berubah dan disesuaikan dengan masalah yang ditemukan pada saat evaluasi. Materi ceramah bersumber dari kajian pustaka pemateri, maupun pengalaman pribadinya.

2) Pendidikan

Tranformasi nilai kepemimpinan juga dilakukan selama proses KBM di SMP dan SMA Ibnu Siena Mulia secara formal. Materi disampaikan oleh guru mata pelajaran masing-masing. adapun mata pelajaran yang mengandung nilai-nilai kepemimpinan di SMP dan SMA Ibnu Siena Mulia seperti:
a) $\mathrm{PKN}$
b) Hadits
c) Akhlak
d) Aqidah
e) SKI (Siroh)
f) Fiqh Dakwah (khusus SMA)
g) Sejarah (khusus SMA)

Nilai-Nilai kepemimpinan disisipi oleh guru mata pelajaran dalam bab tertentu yang mempunyai tema umum kepemimpinan.

3) Uswah hasanah

Penanaman nilai kepemimpinan Islam yang selanjutnya adalah dengan metode uswah hasanah. Uswah hasanah atau percontohan akhlak yang baik dilakukan pertama kali oleh petinggi Pesantren, kemudian guru dan kesiswaan, pengurus OSPIS dan terakhir kepada anggota OSPIS.

Penanaman nilai dengan metode ini dilakukan secara terusmenerus dan berulang ulang, sehingga secara sadar dan tidak sadar, percontohan ini menjadi nilai pribadi yang tertanam dan tertuangkan dalam perilaku dan aktifitas sehari hari. Memang, dalam keadaankeadaan tertentu, percontohan ini sengaja diatur oleh asatidz kesantrian, supaya nanti dapat dicontoh oleh pengurus OSPIS. misal, dalam memutuskan suatu keputusan, asatidz kesantrian menyampaikan terlebih dahulu pertimbangan-pertimbangan logis dari berbagai pendekatan, sehingga lahirnya keputusan tersebut. Dan di ujung nya, dijelaskan beginilah cara pengambilan keputusan dan prosedurnya. 


\section{4) Pelatihan}

Pelatihan ini dilakukan dan diselenggarakan oleh pengurus organisasi untuk kalangannya sendiri dan dihadiri oleh pengurus dan anggotanya. Dalam pelatihan kepemimpinan ini, sebagaimana telah diselenggarakakn sebelumnya, pengurus bersama panitia mengundang salah satu aparat kepolisian, TNI dan motivator bidang kepemimpinan.

Sebagaimana yang peneliti temukan di lapangan, pelatihan kepemimpinan yang diselenggarakan oleh pengurus organisasi tahun lalu, mengundang anggota TNI dalam suatu forum, kemudian secara eksklusif memaparkan materi-materi kepemimpinan kepada pengurus OSPIS tentang bagaimana menjadi pemimpin negara dan apa saja yang harus dipersiapkan oleh para calon pemimpin negara di luar sudut pandang politik.

\section{5) Lingkungan}

Pesantren, secara istilah adalah lingkungan yang sengaja diciptakan untuk mendidik para santri. Dari pengertian di atas, pesantren sangat unggul dalam pendidikan terutama dalam hal lingkungan. Karena lembaga pendidikan lain belum tentu memiliki lingkungan secara 24 jam ditujukan untuk pendidikan.

Realitanya, pendidikan kepemimpinan porsinya lebih banyak dilakukan setelah keluar kelas. Artinya, lingkunganlah yang menentukan kepribadian apa yang akan tertanam pada diri seseorang. Sebagaimana temuan di lapangan, peneliti menemukan porsi peran OSPIS lebih besar dilakukan setelah keluar kelas atau setelah KBM di sekolah berakhir. Lingkungan ini lah yang dibuat semaksimal mungkin, dari mulai sarana, pendidik, juga pengurusnya supaya objek didikannya dan nilai yang tertanam dalam dirinya, merupakan nilai keislaman dan kepemimpinan seperti yang diharapkan.

\section{Hasil}

OSPIS di awal kemunculannya, sebagaimana telah dibahas pada bab sebelumnya, merupakan media yang sengaja diadakan untuk menanamkan nilai nilai kepemimpinan Islam pada diri setiap santrinya, baik dari pengurus itu sendiri, maupun anggotanya. Nilai-nilai kepemimpinan ditanamkan secara inplisit, akan tetapi santri sebagai objek sasaran pendidikan dapat merasakannya.

Dari sekian banyak nilai-nilai kepemimpinan Islam, setidaknya peneliti menggarisbawahi 3 nilai yang terbentuk dari proses kepengurusan OSPIS selama kurang lebih satu tahun kepengurusan mereka. Ketiganya tidak bisa terlepas dari setiap proses kepengurusan, sehingga mau tidak mau nilai-nilai ini terinternalisasi dengan baik lewat pembiasaan dan proses yang panjang sehingga para pengurus faham dan menghayati betul nilai-nilai ini bahkan secara prakteknya. Berikut akan dijabarkan ketiga nilai tersebut:

a) Amanah dan Tanggung Jawab 


\section{BESTARI}

Vol. 17, No. 2, 2020

p-ISSN 1907-1337; e-ISSN 2807-6532

Dalam menjalankan kepengurusan OSPIS, asatidz kesantrian akan menjalankan perannya sebagai controller. Salah satu tugasnya adalah menanamkan rasa "taashub" atau fanatisme kepada pengurus terhadap divisi yang diamanahi kepadanya dengan cara memberikan kebebasan mengelola para anggotanya sesuai divisi masing- masing, menjalankan tugas pokok dan fungsi yang diberikan serta siap menerima konsekwensi atas hasil kinerjanya terhadap anggota OSPIS.

Sebagai contoh, "Nadiya" adalah lulusan Pesantren Ibnu Siena Mulia tahun ajaran 2019-2020. Ia merupakan pengurus OSPIS setahun lalu dan diamanahi divisi pendidikan. Ia bertutur

"Nadiya merasa bahwasaannya divisi itu adalah tanggung jawab Nadiya sendiri, bahkan jika ga amanah, maka a'do yang ga akan bisa keurus sendiri, selain itu kalo urusan masalah pribadi juga belum beres maka ga akan bisa ni ngurus a'do yang lain. Gitu ustad jadi kalo soal tanggung jawab kita dituntut untuk menjadi manusia yang bertanggung jawab atas diri sendiri dan orang lain"

Tanggung jawab dan amanah ini juga berkaitan dengan ruang lingkup kepengurusan. Masalah dan problematika santri yang berkaitan secara internal, akan diselesaikan oleh pengurus OSPIS. Dalam hal ini, kesantrian akan mempertanyakan kinerja OSPIS apabila masalah tersebut tidak dapat diselesaikan oleh mereka. Bahkan dalam kondisi ekstrim, kesantrian akan menghukum pengurus OSPIS jika didapati adanya pelanggaran yang dilakukan oleh santri dalam kepengurusannya. Dari sinilah, rasa amanah dan tanggung jawab sedikit demi sedikit tumbuh.

Amanah dan tanggung jawab yang dibiasakan, berdampak pada terbentuknya mental kepemimpinan. Bagaimana tidak, jika ditanya tentang pemimpin idaman, tentu kriteria "amanah dan bertanggung jawab" tidak akan pernah luput. Sebagaimana penuturan Nadya, sifat tanggung jawab ini melahirkan beberapa sifat lainnya yang terkategorikan sebagai nilai kepemimpinan, seperti berani mengambil tindakan, bijaksana dalam mengambil keputusan dan lain sebagainya.

b) Jiwa Sosial

Organisasi merupakan wadah yang didalamnya terdapat interaksiinteraksi antar anggota maupun pengurusnya. Begitupula organisasi intra Pesantren di Ibnu Siena Mulia ini. Pengurus dituntut untuk cakap dalam berkomunikasi, tidak hanya berkomunikasi ringan tentunya, tapi berkomunikasi ang lebih berbobot, komunikasi yang melahirkan kebijakan dan keputusan untuk masalah kepengurusan dan anggota OSPIS.

Secara langsung, para pengurus OSPIS diajarkan ilmu komunikasi, bagaimana berkomunikasi dengan teman sejawat, dengan anggota, ataupun dengan guru dan asatidz kesantrian. Adapun kepada anggota OSPIS dibutuhkan kecakapan dalam mengkomunikasikan masalah. 
Walaupun masalahnya sama, tapi dihadapi dan dikomunikasikan dengan cara yang berbeda, akan menghasilkan hal yang berbeda pula.

Sama halnya dengan peraturan dan kebijakan yang diberikan Pesantren kepada para santrinya. tugas pengurus OSPIS adalah menkomunikasikan peraturan dan kebijakan kepada anggotanya secara perlahan dan baik, sehingga peraturan tersebut dapat diterima dengan baik oleh anggota, dan pada akhirnya menimimalisir pelanggaran disiplin.

Nadiya, salah satu pengurus OSPIS yang telah menyelesaikan kepengurusannya tahun lalu bertutur saat sesi wawancara tentang hal ini,

"Karakter kepemimpinan mungkin baru Nadiya dapat kan setelah bergabung dalam kepanitian dan kepengurusan di ibsie, setelah Nadiya jaid OSPIS dan panitia di berbagai acara, nah Nadiya belajar dari melihat kinerja masing masing bidang, dan hal yang ga ideal yang dikerjakan seseorang. Misal mengambil alih tugas dan lain- lain, discomunication,, dan pada akhirnya kita tau bahwasaanya organisasi ideal itu sepperti ini... dan dari situ kita dapat berpikir ,oh ternyata dalam berirganisasi ga baik ya seperti ini... dan lain-lain,, jadi banyak sekali hal yang dapat nadiya pelajari"

Dari pemaparan Nadiya di atas bisa disimpulkan bahwa dalam beroganisasi, terdapat pelajaran sosial yaitu "to do" dan "not to do", atau apa yang harus dilakukan, dana apa yang harus dihindari dalam berkomunikasi dan berinteraksi dalam konteks Organisasi.

c) Uswah hasanah

Peneliti mengutip salah satu jawaban narasumber dalam sesi wawancara, seorang santriwati kelas 12 yang sekarang menjadi ketua OSPIS:

"Bismillah. Saya ingin berusaha memberikan uswah kepada anggota saya berupa rasa tanggung jawab, saling memahami, saling merangkul, dan mencoba menjadi pribadi yang lebih baik kedepannya. Meskipun pada hakikatnya saya hanya manusia biasa, tapi dengan amanah ini saya ingin berusaha memantaskan apa yang Allah titipkan kepada saya”

Uswah hasanah merupakan alasan utama pengutusan Muhammad SAW sebagai nabi dan Rosul di muka bumi ini. Sebagaimana difirmankan Allah dalam Alquran, "Sesungguhnya telah ada pada (diri) Rasulullah itu suri teladan yang baik bagimu (yaitu) bagi orang yang mengharap (rahmat) Allah dan (kedatangan) hari kiamat dan dia banyak menyebut Allah (Q.S. Al-Ahzab, 31:21).

Upaya "Nafisa" dalam menjadikan sosok dirinya sebagai panutan dan contoh, terlebih lagi ia dipilih sebagai ketua OSPIS, perlu diapresiasi. Peneliti dalam hal ini menetahui betul bagaimana usaha yang dilakukan "Nafisa" agar menjadi sosok panutan bagi anggotanya dan pengurus lainnya. Secara akademis juga, ia merupakan sosok yang pintar bahkan seringkali menempati posisi pertama di kelasnya.

"Nadiya" ketika ditanya "bagaimana kamu memandang OSPIS sewaktu kamu masih menjadi anggota"? lalu Ia menjawab: 


\section{BESTARI}

Vol. 17, No. 2, 2020

p-ISSN 1907-1337; e-ISSN 2807-6532

"Dulu pas masih jadi anggota nah disitu saya sering banget merhatiin kinerja OSPIS, meskipun dari eksternal, tapi saya juga paham jadinya bagaimana kinerja yang baik, meskipun belum sepenuhnya, setelah itu saya tertarik banget buat ikutan organisasi organisasi, karna emang bermanfaat gitu buat orang lain dan sekitar melihat kakak kakak OSPIS yg tidak bertanggung jawab juga ada, tapi jadinya bikin kita paham ni hal hal yg tidak baik untuk orang lain”.

Pernyataan yang diungkapkan oleh Nadya membuktikan bahwasannya para pengurus OSPIS dituntut untuk menjadi teladan bagi anggotanya. Seluruh tingkah laku pengurus tidak lepas dari pengawasan santri karena memang mereka hidup berdampingan tanpa ada sekat yang memisahkan. Memberi teladan berbeda dengan memberi contoh. Jika pengurus hanya mememberi contoh terhadap anggotanya, berarti pengurus hanya sekedar menyuruh untuk berbuat sesuatu, tanpa adanya penghayatan akan hal itu, bahkan buka termasuk perilakunya sehari-hari, sedangkan memberikan teladan, berarti pelakunya menghayati betul apa yang ia kerjakan, sehingga menjadi perilaku dan tabiat pribadinya.

Pemberian teladan atau Uswah hasanah dari pengurus OSPIS terhadap anggotanya merupakan hal yang urgen mengingat pengurus OSPIS kedepannya, adalah mereka yang sekarang menjadi anggota OSPIS. Apapun itu, baik dan buruknya secara tidak sadar akan membentuk karakter dan pribadi anggota, dan akan terus ditularkan ke generasi pengurus OSPIS berikutnya

\section{SIMPULAN}

Perencanaan internalisasi nilai-nilai kepemimpinan dalam OSPIS Pesantren Ibnu Siena Mulia dilakukan melalui 4 langkah. Langkah pertama pembentukkan penitia, langkah ke dua pelaporan pengurus OSPIS lama, langkah ke tiga pemilihan ketua OSPIS baru, dan langkah ke empat pembentukkan struktur OSPIS baru.

Pelaksanaan internalisasi nilai-nilai kepemimpinan dalam OSPIS Pesantren Ibnu Siena Mulia dilakukan melalui pembagian divisi-divisi dengan tugas pokok dan fungsinya masing masing. Adapun Internalisasi nilai-nilai kepemimpinannya dilakukan dalam 5 bentuk, yaitu ceramah, pendidikan, uswah hasanah, pelatihan dan lingkungan

Internalisasi nilai-nilai kepemimpinan dalam OSPIS Pesantren Ibnu Siena Mulia dapat dirasakan oleh pengurus dan Pesantren dengan terbentuknya sikap amanah, tanggung jawab, jiwa sosial dan Uswah Hasanah

\section{DAFTAR PUSTAKA}

Ad-Dumaiji, Abdullah. (Eds). (2016). Konsep Kepemimpinan dalam Islam (Penerjemah Umar Mujtahid). Jakarta: Ummur Qura. 
Al-Hamdani, M. Djaswidi. (Ed). (2005). Pengembangan Kepemimpinan Tranformasional pada Lembaga Pendidikan Islam. Bandung: Nuansa Aulia.

Andreastuti, Desie. (2014). Analisis Kepemimpinan Partisipatif dalam Pengendalian Kebakaran Hutan dan Lahan. JSP, 18(1), 15-25 Diambil

dari https://jurnal.ugm.ac.id/jsp/article/download/13089/9318 Diakses tanggal 4 Mei 2020

Apriyani, Muthmainnah. (2014). Upaya meningkatkan sikap kepemimpinan pengurus osis melalui sosiodrama di SMA Negeri 1 Kasihan Bantul Yogyakarta. Psikopedagogia, 3(1), 39-50 Diambil dari http://www.garuda.ristekbrin.go.id Diakses tanggal 1 mei 2020 Bahruddin. (2015). Kepemimpinan dalam perspektif Islam. Fikrah, 8(1), 30-54. http://ejournal.uikabogor.ac.id/index.php/FIKRAH/article/download/222/222 diakses 26 Juni 2020

Burhani \& Lawrens, Hasbi. Tt. Kamus Ilmiah Populer Edisi Millenium. Jombang: Lintas Media.

Fadhilah, Lita Nala. (2017). Pendidikan alternatif dengan model $\begin{array}{llll}\text { pesantren salafi-khalafi. } & \text { At-tarbawi, } & \text { 2(1). } & \text { 1-20. }\end{array}$ http://ejournal.iainsurakarta.ac.id/index.php/attarbawi/article/download/667/162 diakses 11 agustus 2020

Faisal. (2018). Internalisasi pendidikan profetik di pesantren. Journal Ar'rihlah, 3(1), 81-93. $\quad$ https://ejournal.iainukebumen.ac.id/index.php/Ar-rihlah/article/view/71/57 diakses 21 juli 2020

Fauzan, Etc. (Eds). (2010). Ensiklopedia Pendidikan Islam. Jilid 5. Depok: CV Binamuda Ciptakreasi.

Fauzan, Etc. (Eds). (2010). Ensiklopedia Pendidikan Islam. Jilid 6. Depok: CV Binamuda Ciptakreasi.

Fitriyani. (2019). Konsep organisasi pendidikan dalam pemberdayaan sekolah. El-Ghiroh, 17(2), 61-80. Doi: https://doi.org/10.37092/elghiroh.v17io2.105 Diambil dari https://jurnal.staibsllg.ac.id/index.php/el-ghiroh/article/view/105 Diakses tanggal 3 mei 2020

Hajar, Siti, et.al. (2019). Pembinaan kesiswaan untuk penumbuhan dan penguatan karakter kepemimpinan melalui kegiatan OSIS. Jurnal Civic Hukum, 4(1), 59-69 Diambil dari http://www.garuda.ristekbrin.go.id Diakses tanggal 1 mei 2020

Husna, Faiqatul. (2017). Kepemimpinan islami dalam meningkatkan mutu lembaga pendidikan Islam. Misykat, 2(2), 131-154. https://media.neliti.com/media/publications/271176kepemimpinan-islami-dalam-meningkatkan-m-ddeeff $35 . p d f$ diakses 26 Juni 2020

Indartono, Setyabudi. (2005) Leadership. Diambil dari https://arwana007.files.wordpress.com Diakses tanggal 2 mei 2020 


\section{BESTARI}

Vol. 17, No. 2, 2020

p-ISSN 1907-1337; e-ISSN 2807-6532

Janah, Yustinah Eka, et.al. (Eds). (2015). Detik-Detik Ujian Nasional Sosiologi. Klaten: PT Intan Pariwara.

Kamus Al-maany. Diambil dari https://www.almaany.com/id/dict/arid/kepemimpinan/ Diakses tanggal 4 Mei 2020

Kamus Besar Bahasa Indonesia (KBBI) Diambil dari https://www.google. com/amp/s/kbbi.web.id/pimpin.html Diakases tanggal 2 Mei 2020

Ma'sum, Toha. (2019). Persinggungan kepemimpinan transformational dengan kepemimpinan visioner dan situasional. Intizam, 2(2), 85106. Diambil dari https://ejurnal.staidakrempyang.ac.id/index.php/intizam/article/view/133/95 Diakses tanggal 2 mei 2020

Masniati. (2015). Kepemimpinan dalam Islam. Jurnal Al-Qadāu, 2(1), 41-75. Diambil dari http://journal.uinalauddin.ac.id/index.php/al-qadau/article/download/2634/2485 diakses 26 Juni 2020

Miqo, Bang. (2016). Mengenal Sang Kekasih. Jakarta: PT Elex Media Komputindo.

Mitsni (2020), Pengertian kepemimpinan: tujuan, teori, fungsi dan contoh leadership. Diambil dari http://Salamadian.com?pengertian-kepemimpinan/. Diakses tanggal 2 Mei 2020

Munfaridah, Tuti. (2012). Kepemimpinan dalam islam. Wahana Akademika, 14(1), 1-33. http://dx.doi.org/10.21580/wa.v14i1.353 Diambil dari https://ejurnal.walisongo.ac.id/index.php/wahana/article/view/35 3 Diakses tanggal 3 mei 2020

Musyarofah. (2016). Internalisasi pesan multikultural pada organisasi pesantren putri stain jember. Inject, 1(2), 181-202. Doi: https://doi.org/10.18326/inject.v1i2.181\%20-202 Diambil dari https://inject.iainsalatiga.ac.id/index.php/INJECT/article/view/65 o/491 Diakses tanggal 3 mei 2020

Nasukah, Binti, et.al. (2020). Internalisasi nilai-nilai kepemimpinan profetik di lembaga pendidikan Islam. Dirasat: Jurnal Manajemen dan Pendidikan Islam, 6(1), 52-68 https://journal.unipdu.ac.id/index.php/dirasat/article/view/1966/ 1028 diakses 21 juli 2020

Nurhadi. (2013). Pembelajaran organisasi di pondok pesantren . Ta'alum, 1(1), 49-62. doi: http://dx.doi.org/10.21274/taalum.2013.1.1.49-62 Diambil dari http://ejournal.iaintulungagung.ac.id/index.php/taalum/article/view/544 Diakses tanggal 3 mei 2020

Nurseno. (Ed). (2011). Theory and Aplication of Sociology. Solo: PT Tiga Serangkai Pustaka Mandiri.

Poerwadarminta, W.J.S. (2011). Kamus Umum Bahasa Indonesia. Edisi 3. Jakarta: PT Balai Pustaka. 
Prameswari, Intan \& Sofro, A'yunin. (2018). Analisis pengaruh gaya kepemimpinan demokratis, permisif dan otoriter terhadap kinerja guru dan profesionalitas guru pada sekolah taman dewasa se kodya Yogyakarta dengan Manova. Jurnal Mahasiswa , 6(2) 117-121 Diambil

dar https://jurnalmahasiswa.unesa.ac.id/index.php/mathunesa/article /viewFile/24324/22251 Diakses tanggal 4 mei 2020

Ramli, Muhammad. (2017). Manajemen dan kepemimpinan pesantren: dinamika kepemimpinan kiai di pesantren. Al-Falah, 17 (2) 125-162 Diambil

dari http//ejurnal.staialfalahbjb.ac.id/index.php/alfalahjikk/article/vie w/20/89 Diakses tanggal 2 mei 2020

Ruchanah, Siti. (2015). Kepemimpinan pendidikan islam dalam perspektif teologis. Jurnal Cendikia, 13 (1), 125-137. Diambil dari https://jurnal.iainponorogo.ac.id/index.php/cendekia/article/dow nload/241/211 Diakses tanggal 4 mei 2020

Saebani, Beni Ahmad \& Sumantri, Ii. (2014). Kepemimpinan. Bandung: Pustaka Setia.

Sakdiah. (2016). Karakteristik kepemimpinan dalam Islam (kajian historis filosofis ) sifat-sifat Rasulullah. Jurnal Al-Bayan, 22(33), 29-49. Diambil dari https://jurnal.arraniry.ac.id/index.php/bayan/article/download/636/540 Diakses 5 Mei 2020

Sarbini. (2013). Konsep kepemimpinan dalam perspektif Islam. Jurnal TAPIs, $9(2)$ 17-29 http://ejournal.radenintan.ac.id/index.php/TAPIs/article/downloa d/1588/1323 diakses 26 Juni 2020

Soedijarto. (1993). Menuju Pendidikan Nasional Yang Relevan Dan Bermutu. Jakarta: Balai Pustaka.

Stiawan, Kelik dan Tohirin, M. (2015). Format pendidikan pondok pesantren salafi dalam arus perubahan sosial di kota Magelang. Cakrawala, $10(2)$, 194-219. https://media.neliti.com/media/publications/58258-ID-formatpendidikan-pondok-pesantren-salaf.pdf diakses 11 agustus

Sukitman, Tri. (2016). Internalisasi pendidikan nilai dalam pembelajaran. JPSD : Jurnal Pendidikan Sekolah Dasar, 2(2), 85-96 https://media.neliti.com/media/publications/71271-ID-none.pdf diakses 21 juli 2020

Sukmadinata, Nana Syaodih. (2010). Metode Penelitian Pendidikan. Bandung: Pt Remaja Rosdakarya Offset.

Tolib, Abdul. (2015). Pendidikan di pondok pesantren modern. Jurnal Pendidikan dan Studi Islam, 1(1), 60-66 http://jurnal.faiunwir.ac.id/index.php/Jurnal_Risalah/article/dow nload/12/7 diakses 11 agustus 2020

Wardianto, M. dan Hendrati, Fabiola. (2014). Korelasi motivasi berprestasi dan kepemimpinan transformasional dengan komitmen 


\section{BESTARI}

Vol. 17, No. 2, 2020

p-ISSN 1907-1337; e-ISSN 2807-6532

organisasi pengurus pondok pesantren. Jurnal Psikologi Indonesia, 3(3). 260-282 Diambil dari http://www.garuda.ristekbrin.go.id Diakses tanggal 1 mei 2020

Widyaningsih, Titik Sunarti, Etc. (2014) Internalisasi Dan Aktualisasi Nilai-Nilai Karakter Pada Siswa Smp Dalam Perspektif Fenomenologis. Jurnal Pembangunan Pendidikan: Fondasi dan Aplikasi, 2(2). 181-195. https://journal.uny.ac.id/index.php/jppfa/article/viewFile/2658/2 213 Diakses 3 Agustus 2020

Zainuddin, Akbar. (Ed). (2014). Ketika Sukses Berawal dari Pesantren. Bekasi: MJWBook. 
